\section{Molecules implicated in glucose homeostasis are differentially expressed in the trachea of lean and obese Zucker rats}

\author{
F. Merigo, ${ }^{1}$ F. Boschi, ${ }^{2}$ C. Lasconi, ${ }^{1}$ \\ D. Benati, ${ }^{1}$ A. Sbarbati ${ }^{1}$ \\ ${ }^{1}$ Department of Neurological and \\ Movement Sciences, Anatomy and \\ Histology Section, University of Verona \\ 2Department of Computer Science, \\ University of Verona, Italy
}

\section{Abstract}

Recent studies indicate that the processes mediated by the (T1R2/T1R3) glucose/sugar receptor of gustatory cells in the tongue, and hormones like leptin and ghrelin contribute to the regulation of glucose homeostasis. Altered plasma levels of leptin and ghrelin are associated with obesity both in humans and rodents. In the present study, we evaluated the ultrastructure of the mucosa, and the expression of molecules implicated in the regulation of glucose homeostasis (GLUT2, SGLT1, T1R3, ghrelin and its receptor) in the trachea of an animal model of obesity (Zucker rats). We found that the tracheal epithelium of obese animals was characterized by the presence of poorly differentiated cells. Ciliated and secretory cells were the cell lineages with greatest loss of differentiation. Severe epithelial alterations were associated with marked deposit of extracellular matrix in the lamina propria. The expression pattern of GLUT2 and SGLT1 glucose transporters was similar in the trachea of both the Zucker rat genotypes, whereas that of T1R3 was reduced in ciliated cells of obese rats. A different immunolocalization for ghrelin was also found in the trachea of obese rats. In conclusion, the tracheal morphological alterations in obese animals seem to compromise the expression of molecules involved in the homeostasis of glucose.

\section{Introduction}

Data from recent studies has revealed that in addition to the processes initiated by the secretory activity of the endocrine pancreas, also those mediated by the same (T1R2/T1R3) glucose/sugar receptor of the gustatory cells in the tongue and the enteroendocrine cells in the intestine, contribute to the regulation of glucose homeostasis. For example, in duodenal epithelium, the expression of glucose transporters (SGLT1, GLUT2) correlates with the levels of luminal monosaccharides and is regulated by the T1R3 subunit of sweet taste receptor and $\alpha$-gustducin. ${ }^{1,2}$ T1R3 is an integral membrane protein that functions as a sweet receptor in the form of T1R2/T1R3 heterodimer, and as a umami (L-amino acids) receptor in the form of T1R1/T1R3. T1Rs belong to the family of $\mathrm{G}$ protein-coupled receptors (GPCRs) which act through $\alpha$-gustducin, phospholipase C- $\beta$ (PLC $\beta 2$ ), inositoltriphosphate (IP3), and transient receptor potential channel M5 (TRPM5) to induce membrane depolarization and release of adenosine triphosphate ATP.,4 The receptors and components of the sweet taste transduction pathway have been implicated as playing a role in glucose sensing because they are distributed in many tissues, such as the taste cells of the tongue, intestinal epithelial cells of the duodenum and mouse pancreatic $\beta$-cells, in which their functional roles are associated with sweet taste and feeding. ${ }^{5,6}$ The same molecules have been also detected in different tracts of the respiratory apparatus of humans and rodents, including the larynx, ${ }^{7}$ nasal respiratory epithelium, ${ }^{8,9}$ trachea, ${ }^{10-14}$ and bronchi, ${ }^{15}$ suggesting that taste transduction mechanisms also operate in the airways.

In the tracheal epithelium, the most frequent and recognizable cells in many species are goblet, ciliated-columnar and basal cells. But further types not defined by a unique morphology and name are also present. They comprise a heterogeneous population which includes cylindrical cells with a thick brush of long microvilli on the apical surface (namely brush or tuft cells), or cells with a long, thin process that extends up to the lumen (namely neuroendocrine cells). Their role is not completely clear, but they are considered chemosensory cells because they express components of the taste-signaling cascade and/or are related to the nerve endings. ${ }^{6}$ So, in the present work, they will be collectively referred to as solitary chemosensory cells (SCCs).

The airway epithelium is exposed to a thin layer of surface liquid (ASL), whose composition and volume are strictly regulated. Among the substances present in ASL there is glucose, whose concentration is lower than in the blood and is of considerable importance for maintenance of the mechanisms controlling glucose homeostasis. ${ }^{16}$ Glucose diffuses into ASL mainly via the paracellular pathway, and is removed by cellular uptake through glucose transporters. ${ }^{16}$ In humans and rats, the predominant glucose transporters are GLUT isoforms in the proximal airway, while SGLT1 appears to be more active in the distal lung. ${ }^{17,18}$ In the airways, the physiological function of glucose transporters is to maintain low glucose levels in $\mathrm{ASL}$, which is an essential requirement to
Correspondence: Dr. Flavia Merigo, Department of Neurological and Movement Sciences, Anatomy and Histology Section, University of Verona, Strada Le Grazie 8, 37134 Verona, Italy. E-mail: flavia.merigo@univr.it

Key words: Obesity; ultrastructure; ghrelin; ghrelin receptor; sweet receptor; immunohistochemistry.

Received for publication: 24 July 2015 .

Accepted for publication: 30 November 2015.

This work is licensed under a Creative Commons Attribution-NonCommercial 4.0 International License (CC BY-NC 4.0)

CCopyright F. Merigo et al., 2016

Licensee PAGEPress, Italy

European Journal of Histochemistry 2016; 60:2557 doi:10.4081/ejh.2016.2557

prevent bacterial colonization or infection in humans and rodents. ${ }^{19,20}$ In human studies, ASL glucose concentrations were found to be elevated in respiratory diseases and to be associated with hyperglycemia, cystic fibrosis or diabetes..$^{21-26}$ In general, the chemoreceptive epithelia respond to local sugar changes by regulating uptake through a direct effect on glucose transporter expression, or an indirect effect involving different pathways (i.e., hormonal, neural, paracrine, autocrine) ${ }^{27}$ In this regard, the investigation of glucose transporter and glucose-sensing molecule expression in diseases such as diabetes and obesity can be helpful in understanding how airway epithelial cells respond to altered ASL glucose homeostasis.

Recently, considerable attention has been devoted to the role of the two hormones leptin and ghrelin in the control of blood glucose homeostasis. ${ }^{28}$ Ghrelin, the endogenous ligand of the Growth Hormone (GH) Secretagogue type 1a Receptor (GRLN-R), is mostly secreted by endocrine cells of the gastric mucosa in rats and humans, but it exists, along with its receptor, in a wide variety of cells and tissues, including the hypothalamus, small intestine, lung, skeletal muscle, ovary, testis, pituitary gland and pancreas..$^{29}$ Leptin is primarily synthesized and secreted by adipocytes and exerts its activity through the leptin receptor (Ob-R). Leptin and $\mathrm{Ob}-\mathrm{R}$ are expressed in a variety of tissues, such as the hypothalamus, lung, olfactory system, pancreas and taste bud cells of the tongue.$^{30}$ In rodents, deficiency of leptin or leptin receptor gene has generated animal models of obesity that have been widely used to understand the processes involved in the regulation of glucose homeostasis. ${ }^{31}$ Leptin deficient $\mathrm{ob} / \mathrm{ob}$ mice and $\mathrm{Ob}-\mathrm{R}$ deficient $\mathrm{db} / \mathrm{db}$ mice develop hyperphagia, morbid obesity, infertility, and reduced linear growth. Homozygous 
Zucker rats with fa/fa genotype are leptin resistant, hyperphagic and obese; the obese condition is evident at 5 weeks of age. In these animals, the $f a$ mutation in the $O b-R$ gene causes an amino acid substitution in the extracellular domain of $\mathrm{Ob}-\mathrm{R}$, preventing the expression of the receptor long (active) form. Ghrelin is an orexigenic mediator which, apart from its role in the regulation of appetite and on growth hormone secretion, has many functions, including gastrointestinal, cardiovascular, and immune functions. ${ }^{28,32}$ Leptin is an anorexigenic mediator that plays an important role in the regulation of food intake, energy expenditure, metabolism, neuroendocrine axis, and immune function. ${ }^{30}$

Certainly, the most extensively studied role of ghrelin and leptin is their regulatory effect on glucose homeostasis. The literature regarding pharmacological treatment as well as genetic manipulation in rodents, demonstrates that ghrelin inhibits glucose-stimulated insulin secretion, ${ }^{28,33}$ while leptin prevents proinsulin synthesis..$^{30}$ Due to these functions, circulating levels of ghrelin and leptin have been evaluated in metabolic diseases to understand whether dysregulation of their secretion could have a pathophysiological significance. Increased levels of leptin have been found in overfed and obese states, ${ }^{30}$ and increased levels of ghrelin in healthy humans and mice with elevated blood glucose levels. ${ }^{34}$ In contrast, low plasma ghrelin levels are associated with obesity, insulin resistance, metabolic syndrome, also in association with type 2 diabetes mellitus (T2DM) in humans, or with overfeeding, and high fat diet in rats. ${ }^{35,36}$ However, it should be borne in mind that ghrelin and leptin act at both the local level via their specific receptors (autocrine/paracrine), and the systemic (endocrine) level. Indeed, it might be expected that changes in circulating levels of ghrelin and leptin would reflect altered expression and/or distribution of the locally produced hormones, leading to dysregulation of their pathway. Therefore, the expression of these molecules and receptors in peripheral organs may be indicative of their role in glucose homeostasis.

On this basis, the present study was conducted to investigate the expression of molecules implicated in the regulation of glucose homeostasis in the tracheal epithelium of an animal model of genetic obesity. In particular, we evaluated i) the fine structure of the mucosa; and ii) the expression of T1R3, $\alpha$ gustducin, GLUT2, SGLT1, ghrelin, and ghrelin receptor in the trachea of lean $f a /+$ and obese fa/fa Zucker rats.

\section{Materials and Methods}

\section{Animals}

Fourteen male obese ( $f a / f a)$ and 12 male lean $(f a /+)$ Zucker rats were purchased from Harlan Laboratories Srl (Correzzana, MI, Italy) at 8 weeks of age. They were kept in individual cages with ad libitum access to standard rat chow and tap water under controlled temperature, humidity, and light cycle conditions. The animals were acclimatized to the local facilities for at least two weeks before being used for the study. At the time of experimental sessions, their ages ranged from 10-18 weeks for both Zucker rat genotypes; their body weight ranged from $285 \mathrm{~g}$ to $340 \mathrm{~g}$ for lean, and from $338 \mathrm{~g}$ to $498 \mathrm{~g}$ for obese rats. Concurrently, 1012-week old male Wistar rats $(n=6$, weight 150-200 g; Morini Co., Reggio Emilia, Italy), were similarly housed. Their immunohistochemical analyses were compared with those of the Zucker rats. The experimental animal protocol was prospectively approved by the Italian Ministry of Health and by the University Commission for Animal Care.

\section{Tissues}

The animals were anesthetized with isoflurane (3\% by inhalation) and perfused with $4 \%$ paraformaldehyde in phosphate buffer. Proximal tracheae were quickly collected. For immunohistochemical microscopy, tissues were further fixed by immersion in the same fixative, rinsed and put into $30 \%$ sucrose overnight. Sections (40 $\mu \mathrm{m}$ thickness) were cut on a freezing microtome (Reichert-Jung, Vienna, Austria) and processed for both immunoperoxidase and immunofluorescence labeling.

\section{Transmission Electron Microscopy}

For ultrastructural examination, small tissue blocks were further fixed with $2 \%$ glutaraldehyde in phosphate buffer for $2 \mathrm{~h}$ at $4{ }^{\circ} \mathrm{C}$, postfixed in $1 \% \mathrm{OsO}_{4}$, dehydrated and embedded in a mixture of Epon and Araldite (Electron Microscopic Sciences, Fort Washington, PA, USA). Semithin sections ( $2 \mu \mathrm{m}$ thickness) were stained with toluidine blue, and examined using an Olympus BX51 microscope connected to a digital camera (JVC CCDKY-F58) equipped with the image analysis digital system Image-Pro Plus 7.0 (Media Cybernetics, Silver Spring, MD, USA). Ultrathin sections were cut at a thickness of $70 \mathrm{~nm}$ on an Ultracut-E ultramicrotome (Reichert-Jung), stained with lead citrate and observed in a Morgagni 268D transmission electron microscope equipped with a Megaview II camera for digital image acquisition (FEI Company Philips, Milan, Italy). The images deriving from toluidine blue stained sections of 6 lean and 7 obese Zucker rats (one section per animal) were randomly selected and used to measure diameter and area of lipid droplets (LDs) in the lamina propria, vessels and cartilage. Three optical fields per section were observed at $60 \mathrm{x}$ magnification. In the lamina propria, the lipid deposition was measured by tracing the borders of the LDs on the images, and by measuring the inner area. In vessels, the lipid deposition was measured as done previously in the lamina propria, and also by measuring the area covered by the vessels. The ratio between the area of the lipid deposition and the corresponding area of the vessel was evaluated. In the cartilage, the diameter of the almost perfectly round in shape LDs was evaluated. Measurements were done by using the software ImageJ (NIH, Bethesda, MD, USA). A statistical analysis was performed using the $t$-test with the level of statistical significance set at 0.05 . The statistical analysis was conducted with Matlab 7.1 (Mathworks, Natick, MA, USA).

\section{Primary antibodies}

For this study we used the following primary antibodies: rabbit anti-ghrelin (Phoenix Pharmaceuticals Inc., Burlingame, CA, USA, cat \#H-031-31); rabbit anti-GLUT2 (also known as -SLC2A2, LifeSpan Biosciences Inc., Seattle, WA, USA, cat \#LS-C15390/25520); rabbit anti$\alpha$-gustducin (Santa Cruz Biotechnology Inc., Heidelberg, Germany, cat \#sc-395); rabbit antighrelin receptor (-GRLN-R Abcam, Cambridge, UK, cat \#ab85104), rabbit anti-SGLT1 (also known as -SLC5A1, Abcam, cat \#ab14686), rabbit anti-T1R3 (Abcam, cat \#ab74732), mouse anti-acetylated $\alpha$-tubulin (Abcam, cat \#ab24610).

\section{Immunohistochemistry}

Peroxidase-immunohistochemistry and immunofluorescence were performed as described in Merigo et al. ${ }^{12}$ Briefly, endogenous peroxidase was quenched by immersion in a peroxidase blocking reagent (DAKO, Milan, Italy), for $20 \mathrm{~min}$. After washing in phosphate-buffered saline (PBS) buffer, pH 7.5 , sections were treated with a blocking solution (0.3\% Triton X-100, $1 \%$ bovine serum albumin BSA and 2\% normal swine serum) for $1 \mathrm{~h}$, and then incubated overnight with the primary antibodies diluted with blocking solution. After washes, sections were then reacted with biotinylated swine anti-rabbit immunoglobulins (DAKO) diluted 1:400 for $1 \mathrm{~h}$. The immunoreaction was detected using a Vectastain ELITE ABC kit (Vector, Burlingame, CA, USA) and then visualized with 3.3 diaminobenzidine tetrahydrochloride (DAK0) for 5-10 min.

Control sections were prepared by preabsorbing the primary antibodies with the corre- 
sponding peptide ( $5 \mu \mathrm{g} / 1 \mathrm{~mL}$ of antibody; Ghrelin peptide, Phoenix Pharmaceuticals Inc.; Ghrelin Receptor peptide, Abcam; GLUT2 peptide, Chemicon International Inc., Temecula, CA, USA; SGLT1 peptide, Abcam), or by omitting the primary antibody. Sections were observed on an Olympus BX51 microscope. Images were analyzed and stored using Image-Pro Plus software.

For double immunofluorescent staining, free floating sections were incubated overnight in a mixture of mouse anti- $\alpha$-tubulin antibody with rabbit anti-GLUT2, or -SGLT1, or - $\alpha$-gustducin, or -T1R3 antibody, then washed and incubated in a mixture of secondary antibodies (TRITC-conjugated goat antimouse and FITC-conjugated goat anti-rabbit; Jackson Laboratories, Baltimore, PA, USA; 1:200) for $1 \mathrm{~h}$. Control sections were prepared as described above.

When the glucose transporter immunolabeling was compared with that of ghrelin, the double-label assay was carried out sequentially using a method which relied on the use of secondary monovalent Fab fragments, because all primary antibodies are raised in the same species. ${ }^{37,38}$ The double staining was performed as described in Merigo et al. ${ }^{12}$ Control sections were prepared using one of the following methods: i) adding the corresponding peptide to primary antibodies; or ii) replacing the second primary antibody with normal rabbit serum; or iii) exchanging the fluorophores of the secondary antibodies; or iv) omitting the primary antibody; or v) changing the sequence of secondary antibody application. Sections were observed using Leica confocal TCS-SP5 microscope (Leica Microsystems Srl, Milan, Italy); images were acquired using LAS AF Lite software (Leica Microsystems) and processed using Image J software for the selection of the thresholds in each channel and the merging of the channels.

\section{Results}

\section{Light and transmission electron microscopy analysis of trachea in lean and obese Zucker rats}

Using light and transmission electron microscopy, the tracheal mucosa of Zucker rats was observed in the following compartments: epithelium, connective tissue and cartilage.

\section{Epithelium}

In lean Zucker rats, the epithelial cells had an ultrastructural appearance similar to that of normal epithelium. All the major cell types were represented. The ciliated cells appeared well preserved, showing a consistent number of cilia and numerous mitochondria concen- trated just beneath the ciliary basal bodies (Figure 1A-C). Lysosomes were observed in the supranuclear region. The mucous cells exhibited the classical aspects of secretory cells, showing an extensive, cisternal ergastoplasm in the basal part, and numerous mucous droplets, often coalescing, in the apical cytoplasm (Figure 1C). Secretory serous cells were well-represented and well-differentiated, with apical membrane-bound droplets, basal ergastoplasm, numerous mitochondria, and a low nucleus/cytoplasm ratio (Figure 1 C,D). The tracheal epithelium also showed other types of cells, including SCCs, a heterogeneous population which included brush and tuft cells
(Figure 1E). Brush cells, recognizable by a brush of microvilli on the apical surface, contained glycogen granules and a preponderance of agranular reticulum in the cytoplasm (Figure 1 F,I). Clusters of different types of SCCs were distributed throughout the epithelium, and easily distinguishable by the presence of brush cells (Figure $1 \mathrm{G}, \mathrm{I}$ ). A small number of blood cells were also seen; most often they were lymphocytes. Adjacent to the basement membrane there were basal cells with their typical appearance consisting of a large nucleus, scarce cytoplasm and few organules (Figure 1D).

In obese Zucker rats, the trachea showed
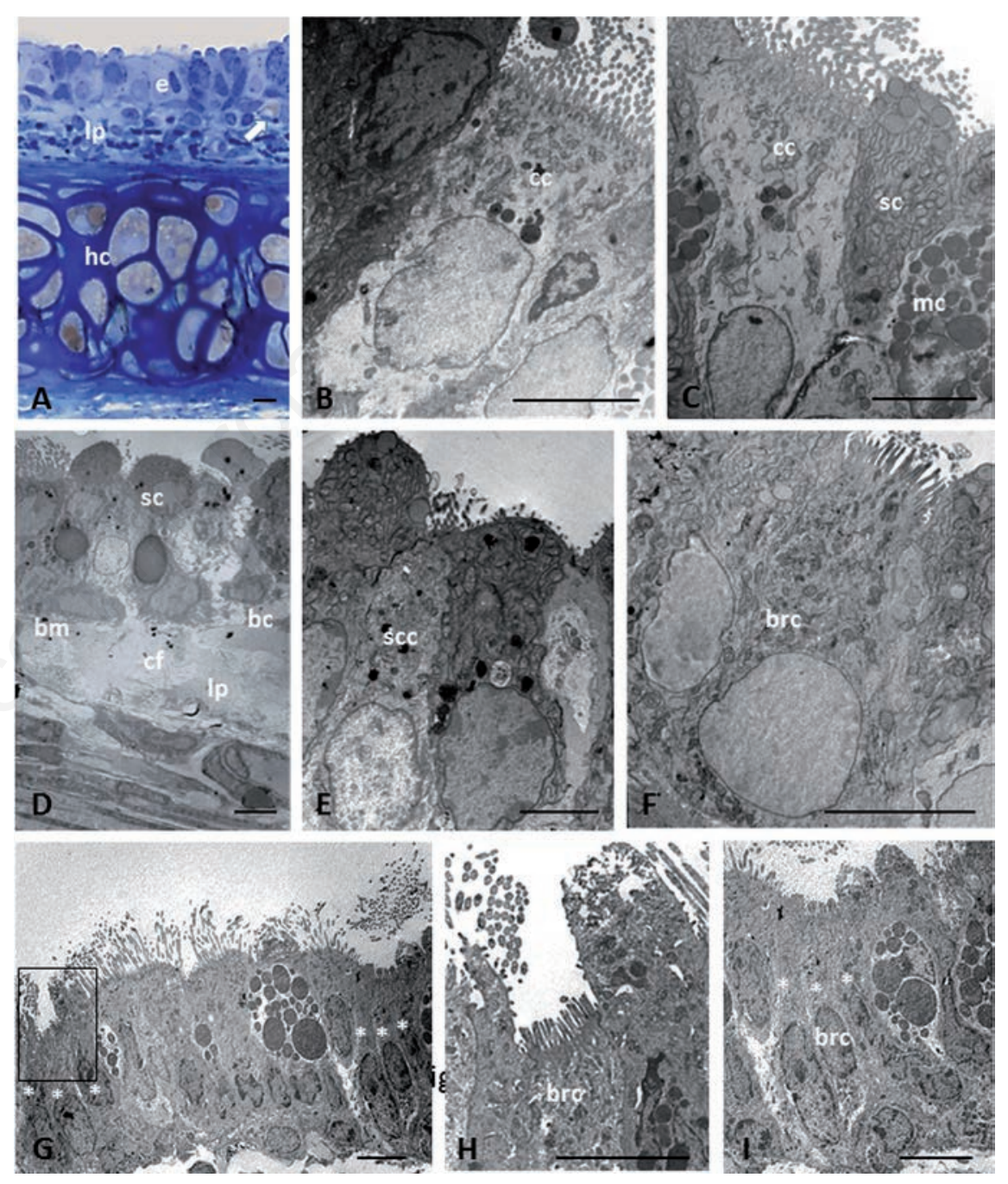

Figure 1. Light (A) and electron microscopy (B-I) showing histological and ultrastructural examinations of epithelium in trachea of lean Zucker rats. Histological section stained with toluidine blue (A). Arrow in (A) indicates lipid droplet. Asterisk indicates the cells that compose a cluster of solitary chemosensory cells. The boxed area on the left in panel $\mathrm{G}$ is shown at higher magnification in $(\mathrm{H})$; the cells marked with asterisks on the right in (G) are shown at higher magnification in panel I. bc, basal cell; bm, basement membrane; brc, brush cell; cc, ciliated cell; cf, collagen fibers; hc, hyaline cartilage; e, epithelium; lp, lamina propria; mc, mucous cell; sc, secretory cell; scc, solitary chemosensory cell. Scale bars: $5 \mu \mathrm{m}$. 
ultrastructural alterations with different degrees of severity. In all obese animals, the epithelium appeared to lose its regular pseudostratified organization over large areas, with certain areas in which a superposition of cell layers was visible, with subsequent epithelial thickening and an increased number of cells (Figure 2A). Epithelial regions monolayered or incompletely stripped were also observed. These severe epithelial alterations were associated with marked deposits of material in the lamina propria (Figure 2B). The epithelium was characterized by the presence of poorly differentiated cells, which were considered intermediate cells. Ciliated and secretory cells were the cell lineages with greatest loss of differentiation. Intermediate ciliated cells had polymorphic aspects: they varied from cells with few cilia but well-represented organules (i.e., mitochondria, endoplasmic reticulum, Golgi apparatus), to cells characterized by few cilia, a decreased number of apical mitochondria, a hypertrophic Golgi apparatus, and numerous lysosomes in the Golgi apparatus zone. A decrease in the number of cilia was often associated with an increase in the number of microvilli on the apical surface. Intermediate secretory cells contained few secretory granules and numerous lysosomes (Figure 2 C,D). Necrotic and swollen cells with a depletion of cytoplasmic organelles were also observed. In contrast, chemosensory elements were well represented both quantitatively and qualitatively. In particular, brush cells appeared to be mature, occasionally hypertrophic, and rich in mitochondria, glycogen granules, and elements of smooth endoplasmic reticulum (Figure 2 D-F). The Golgi apparatus
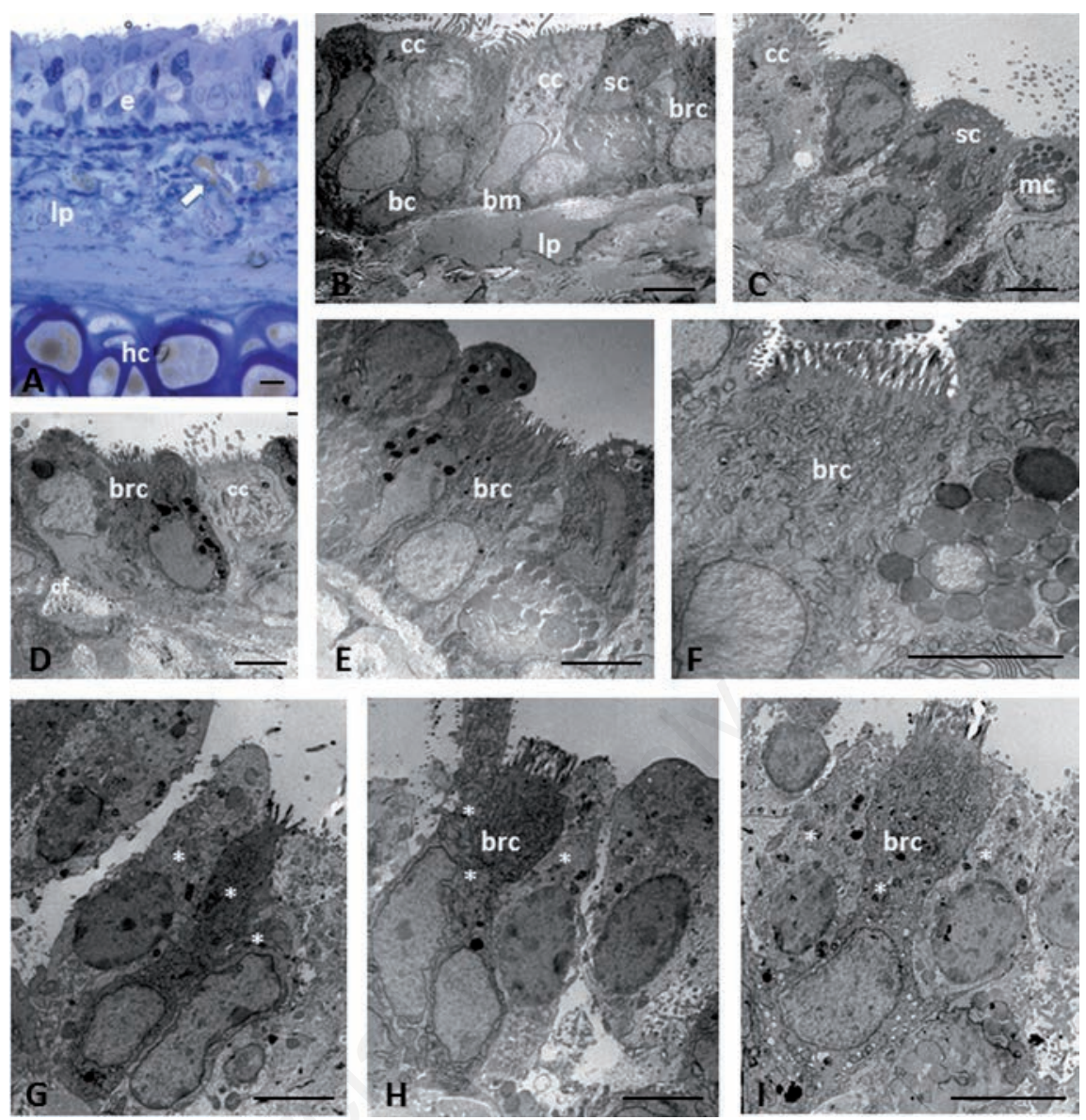

Figure 2. Light (A) and electron microscopy (B-I) showing histological and ultrastructural examinations of epithelium in trachea of obese Zucker rats. Histological section stained with toluidine blue (A). Arrow in (A) indicates lipid droplet. Asterisk indicates the cells that compose a cluster of solitary chemosensory cells. bc, basal cell; bm, basement membrane; brc, brush cell; cc, ciliated cell; hc, hyaline cartilage; e, epithelium; lp, lamina propria; mc, mucous cell; sc, secretory cell. Scale bars: $5 \mu \mathrm{m}$.

Table 1. Measure of the lipid deposition in lamina propria in Zucker rats.

$\begin{array}{lccccc} & \begin{array}{c}\text { Number } \\ \text { of lipid droplets }\end{array} & \begin{array}{c}\text { Minimum lipid } \\ \text { droplet area }\left(\mu^{2}\right)\end{array} & \begin{array}{c}\text { Maximum lipid } \\ \text { droplet area }\left(\mu^{2}\right)\end{array} & \begin{array}{c}\text { Mean } \\ \text { lipid droplet area }\left(\mu^{2}\right)\end{array} & \begin{array}{c}\text { STD } \\ \text { lipid droplet area }\left(\mu^{2}\right)\end{array} \\ \text { Lean } & 14 & 72.98 & 481.32 & 182.25 & 115.4657 \\ \text { Obese } & 25 & 51.01 & 807.74 & 289.67 & 186.8022\end{array}$

Table 2. Measure of the lipid deposition in vessels in Zucker rat.

\begin{tabular}{|c|c|c|c|c|c|c|}
\hline & $\begin{array}{c}\text { Mean } \\
\text { Vessel } \\
\text { area }\left(\mu^{2}\right)\end{array}$ & $\begin{array}{c}\text { STD } \\
\text { Vessel } \\
\text { area }\left(1^{2}\right)\end{array}$ & $\begin{array}{c}\text { Mean } \\
\text { lipid deposit } \\
\text { area }\left(\mathrm{f}^{2}\right)\end{array}$ & $\begin{array}{l}\text { STD } \\
\text { lipid deposit } \\
\text { area }\left(\mu^{2}\right)\end{array}$ & $\begin{array}{c}\text { Mean } \\
\text { lipid deposit/ } \\
\text { vessel area ratio }\end{array}$ & $\begin{array}{c}\text { STD } \\
\text { lipid deposit } \\
\text { /vessel } \\
\text { area ratio }\end{array}$ \\
\hline Lean & 149.85 & 83.11 & 56.82 & 33.05 & $37.5 \%$ & $6.18 \%$ \\
\hline Obese & 156.52 & 103.80 & 66.51 & 34.70 & $45.1 \%$ & $9.59 \%$ \\
\hline
\end{tabular}

Table 3. Measure of the lipid droplet diameter in cartilage in Zucker rats.

\begin{tabular}{|c|c|c|c|c|c|}
\hline & $\begin{array}{c}\text { Mean } \\
\text { Number of lipid } \\
\text { droplet/cell }\end{array}$ & $\begin{array}{l}\text { Minimum } \\
\text { lipid droplet } \\
\text { diameter ( } 1 \text { ) }\end{array}$ & $\begin{array}{l}\text { Maximum } \\
\text { lipid droplet } \\
\text { diameter ( } 1 \text { ) }\end{array}$ & $\begin{array}{c}\text { Mean } \\
\text { lipid droplet } \\
\text { diameter }(\mu)\end{array}$ & $\begin{array}{c}\text { STD } \\
\text { lipid droplet } \\
\text { diameter (1) }\end{array}$ \\
\hline Lean & 5.00 & 0.71 & 8.57 & 2.68 & 2.00 \\
\hline Obese & 2.36 & 0.97 & 9.10 & 3.80 & 2.92 \\
\hline
\end{tabular}


was generally well-developed. Microvilli were of normal length and quantity, and appeared to be associated with low-density bodies on the free luminal side. Clusters of SCCs, closely connected to each other, were present (Figure 2 G-I). They appeared well preserved, even in tracts where the epithelium was characterized by necrotic cells. Basal cells were found in the areas with pluristratified epithelium; they were rare or absent in those with monostratified epithelium. Many elements related to the lymphatic line were often observed.

\section{Connective tissue}

As observed at light and electron-microscopic level, the lamina propria was normal in shape in the majority of lean rats. However, the mucosa from 3 lean animals showed a mildly different morphology due to the presence of areas with an increased thickness of the lamina propria (about 3-5 $\mu \mathrm{m}$ ) just below the basal membrane, but without an apparent alteration of the overlying epithelium. These alterations were limited to small zones and coexisted with extensive traits with normal morphology.

In obese rats, a common feature was the presence of a thick lamina propria, with a thickness about twice that observed in lean rats. It ranged from 8 to $14 \mu \mathrm{m}$ over large areas of the mucosa. The matrix formed a thick layer of amorphous appearance, devoid of elements in the interior, or with branches of collagen fibers (Figure $3 \mathrm{~A}$ C). The substantial deposits of extracellular matrix were associated with severe alterations of the overlying epithelium. Scarce leukocyte infiltration was observed in lean rats, while a significant infiltrate (lymphocytes, eosinophils and mast cells) was present in the lamina propria of obese rats. LDs were found in the connective tissue and around the vessels; they were generally larger in size in obese compared with lean rats. In the lamina propria and submucosal layer, the LDs ranged in area from 72.98 to $481.32 \mu^{2}$ in lean, and 51.01 to $807.74 \mu^{2}$ in obese animals (Table 1). In these latter, some droplets of considerable size (30-40 $\mu \mathrm{m}$ in diameter) were localized in the deepest part of the mucosa. The difference in LDs' area was not statistically significant $(\mathrm{P}=0.0592)$ in the two Zucker rat genotypes. Both in lean (Figure 3D) and obese animals (Figure 3G), the microvascular structures of the connective layer were characterized by the presence of dense deposits that were sometimes visible at the level of subendothelial space, with aspects of endothelial activation such as duplication and fragmentation of the basement membrane of the capillaries. We estimated that they were present in $22 \%$ of the submucosal vessels in samples from lean rats, and $75 \%$ in those from obese rats. The dense deposits occupied on average the $37.5 \%$ of the area of the vessel (36 vessels) in lean rats, versus a $45.1 \%$ observed in obese rats (48 vessels), as shown in Table 2. The difference in the area covered by lipid deposits and the respective area of the vessels was statistically significant in the two Zucker rat genotypes $(\mathrm{P}=0.0246)$. At high magnification, they appeared to consist of rounded particles, homogeneously dense, most likely formed from liposomes associated with denser material probably of protein nature (Figure 3H).
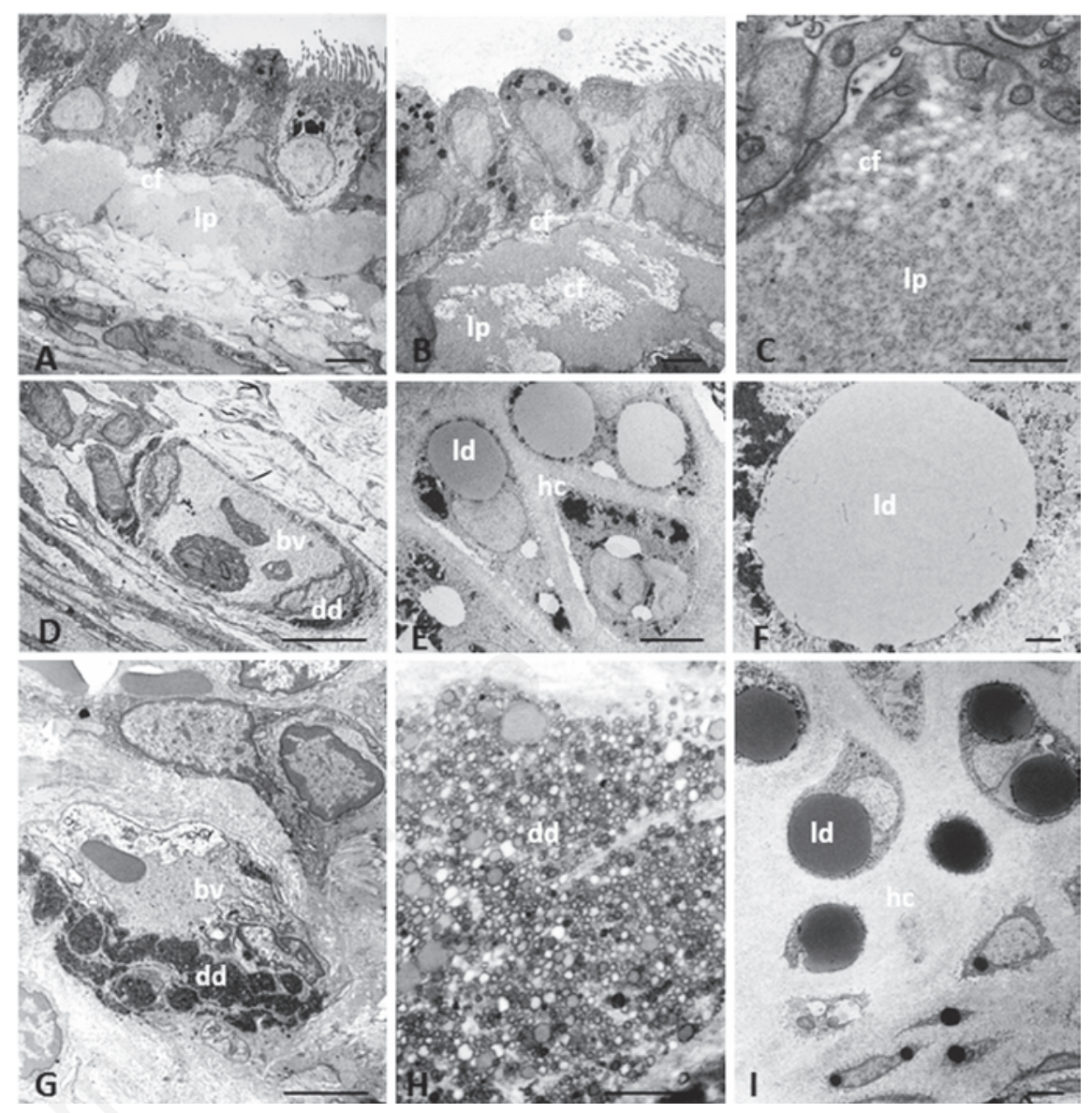

Figure 3. Transmission electron microscopy showing ultrastructural characteristics of trachea in lean and obese Zucker rats. Amorphous material is present in lamina propria of obese Zucker rats (A-C). Dense deposits are present in microvascular structure in lean (D) and obese (G) Zucker rats. The dense deposit in (G) is shown at higher magnification in (H). Lipid droplets are visible in hyaline cartilage of lean (E, F) and obese (I) Zucker rats. bv, blood vessel; cf, collagen fibers; dd, dense deposit; hc, hyaline cartilage; ld, lipid droplet; lp, lamina propria. Scale bars: A,B,D,E,G,I) $5 \mu \mathrm{m}$; C,F,H) $1 \mu \mathrm{m}$.

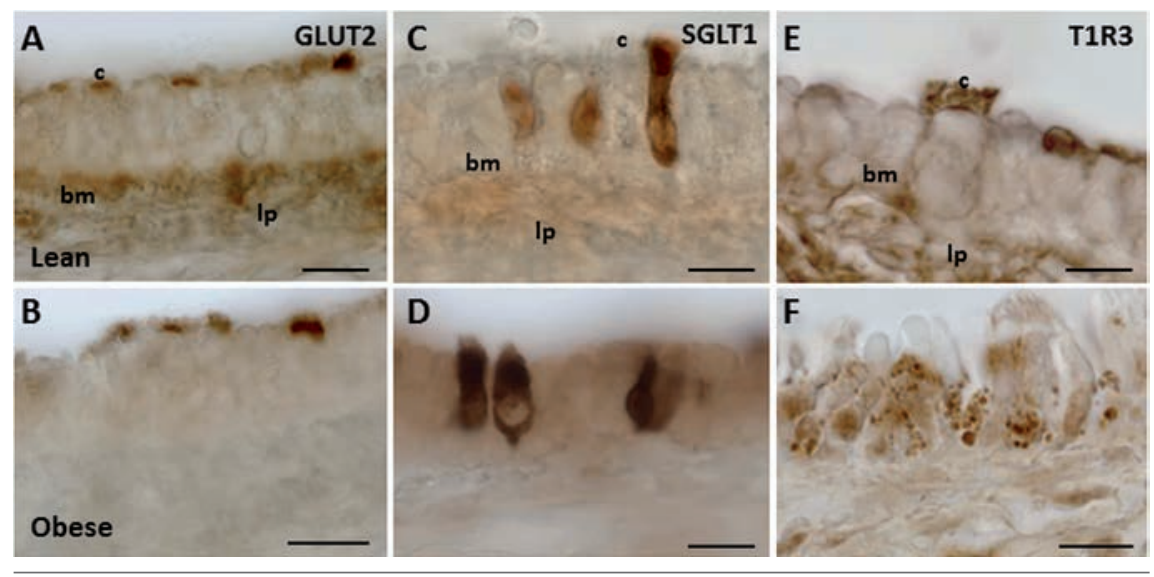

Figure 4. GLUT2, SGLT1, and T1R3 expression in trachea of Wistar and Zucker rats. The immunoperoxidase staining is shown in the epithelium of lean $(A, C, E)$, and obese Zucker $(\mathrm{B}, \mathrm{D}, \mathrm{F})$ rats. bm, basement membrane; c, cilia; lp, lamina propria. Scale bars: $10 \mu \mathrm{m}$. 
Cartilage

In lean rats, the tracheal cartilage had no significant structural alterations. In the central mass of the cartilage, oval and rounded chondrocytes showed a cytoplasm with abundant glycogen and spherical, homogeneously dense LDs (Figure 3E). On average, in each cell the intracellular lipid pattern consisted in 5 droplets whose size rarely exceeded that of the nucleus. The majority of the LDs were surrounded by a rim of fine granules showing a black electron density (Figure 3F). In obese rats, the size of the largest droplet was often bigger than the nucleus, which was either displaced towards the periphery of the cell, or not detectable inside the cell (Figure 3I). Frequently, the LDs were surrounded by fine electron-dense granules which were also scattered inside the drops. The quantitative analysis of 65 LDs in 13 cells and of 33 LDs in 14 cells in lean and obese rats, respectively, is reported in Table 3. In the two Zucker rat genotypes, the difference in LDs' diameter was statistically significant $(\mathrm{P}=0.0272)$.

Immunohistochemical analyses of glucose sensing molecules in trachea of lean and obese Zucker rats

Immunohistochemical analyses were performed using light immunohistochemistry and immunofluorescence experiments.

\section{GLUT2, SGLT1, T1R3, and}

\section{$\alpha$-gustducin expression}

The expression pattern of glucose transporters (GLUT2 and SGLT1) in the trachea of lean and obese Zucker rats was similar to that observed in Wistar rats in our previous work. ${ }^{12}$ In particular, GLUT2 labeling was detected on the apical surface of ciliated cells, just below the cilia, and in the cytoplasm of some non-ciliated cells in both Zucker rat genotypes (Figure 4 A,B). However, not all ciliated cells showed GLUT2 immunoreactivity. SGLT1 immunoreactivity was exclusively observed throughout the entire cytoplasm of cells that appeared as non-ciliated, flask- or pear-shaped cells, with a body localized on the basement membrane and an apical process protruding into the lumen. These cells were regarded as SCCs. No differences between lean and obese rats were observed in SGLT1 expression (Figure $4 \mathrm{C}$ and $\mathrm{D}$, respectively).

The expression pattern of T1R3 was dissimilar in the two Zucker rat genotypes. In lean Zucker rats, T1R3 expression was basically similar to that observed in Wistar rats. ${ }^{12}$ T1R3 immunostaining was detected as spots along the cilia, or on the apical surface and the basolateral membrane (Figure 4E). In obese Zucker rats, T1R3 expression was either decreased or completely absent at the sites specified above. Here, T1R3 labeling was found in vesicles dif-
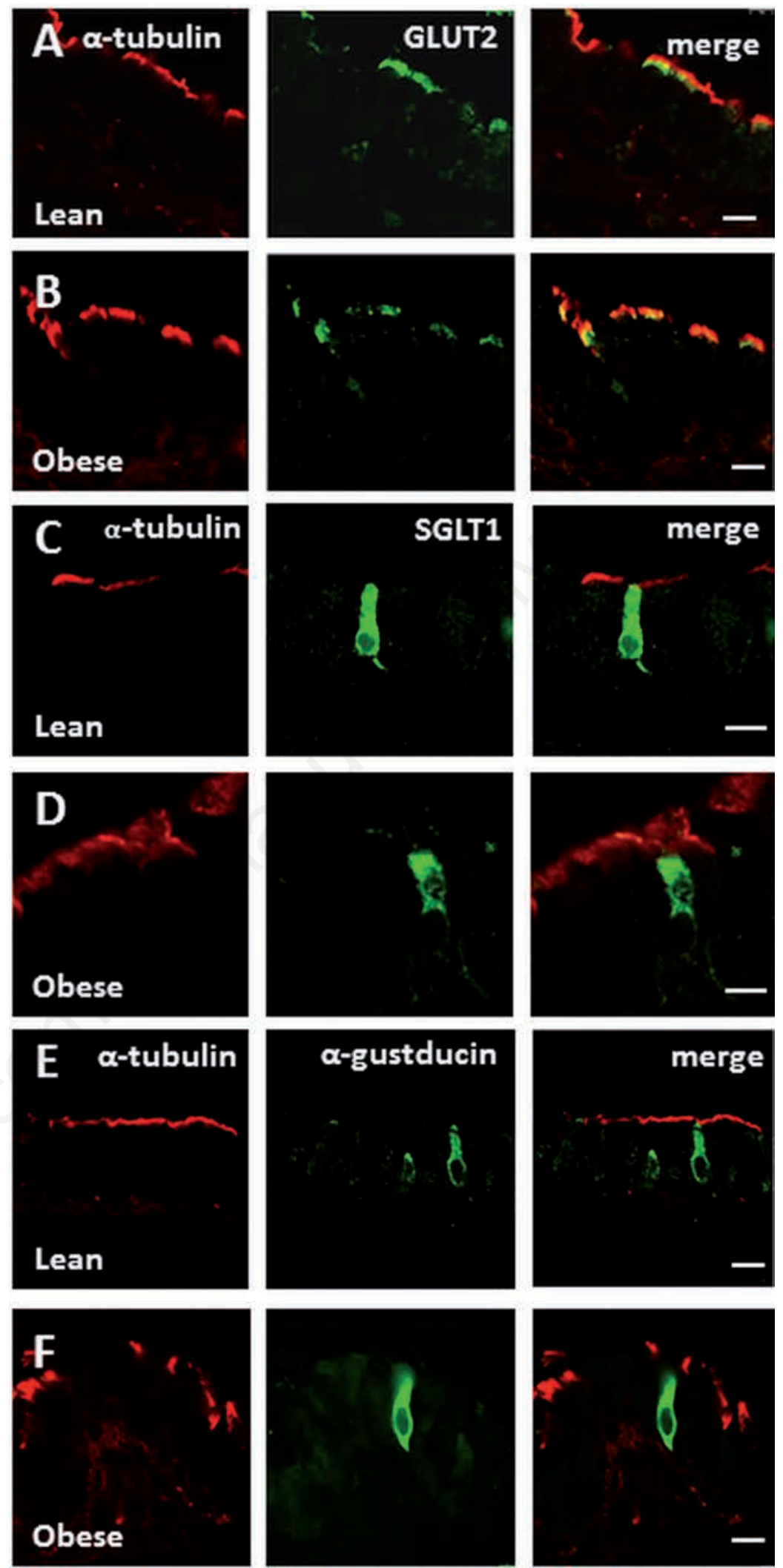

Figure 5. Double-confocal microscopy for $\alpha$-tubulin with GLUT2, SGLT1, $\alpha$-gustducin in trachea of Zucker rats. The immunofluorescence staining shows expression of $\alpha$-tubulin (red) with GLUT2 (green; lines A, B), or SGLT1 (green; lines C, D), or $\alpha$-gustducin (green; lines E, F) in the epithelium of lean (lines A, C, E) and obese (lines B, D, F) Zucker rats. Immunostaining for GLUT2 is expressed by $\alpha$-tubulin immunoreactive cells. SGLT1 and $\alpha$-gustducin immunoreactivities are observed in $\alpha$-tubulin-negative cells identified as solitary chemosensory cells. Scale bars: $10 \mu \mathrm{m}$. 
ferently distributed in the cell cytoplasm (Figure 4F). In both Zucker rat genotypes, T1R3 staining was also observed in the cytoplasm of non-ciliated cells, similar to that detected in Wistar rats. ${ }^{12}$

The expression patterns of glucose transporters and T1R3 were further validated in both Zucker rat genotypes by dual labeled immunofluorescence experiments, using antibody to acetylated $\alpha$-tubulin as a cilia marker, and $\alpha$-gustducin as a marker of chemoceptive cells. By laser-scanning confocal microscopy, the comparison of $\alpha$-tubulin with GLUT2 and SGLT1 antibodies showed similar results in lean and obese rats. In particular, $\alpha$-tubulinpositive cells were also GLUT2 positive, but the staining was not colocalized, being that of $\alpha$ tubulin on the cilia, and GLUT2 at the base of the cilia. However, not all $\alpha$-tubulin-positive cells were also GLUT2-immunoreactive (Figure $5 \mathrm{~A}, \mathrm{~B})$. Through a comparison of $\alpha$ tubulin and SGLT1 antibodies, SGLT1 expression was never found colocalized with $\alpha$-tubulin, confirming that SGLT1-immunoreactivity is selective for chemosensory cells but absent in other cell types (Figure $5 \mathrm{C}, \mathrm{D}$ ). In this regard, to verify whether SCCs retain their immunohistochemical phenotype, we also compared $\alpha$-tubulin with $\alpha$-gustducin. As expected, we observed $\alpha$-gustducin-immunoreactive cells that did not express $\alpha$-tubulin in both Zucker rat genotypes (Figure 5 E,F). The comparison of $\alpha$-tubulin and T1R3 expression produced different results in lean and obese Zucker rats. In lean rats, coexpression of $\alpha$ tubulin and T1R3 was observed in cilia. T1R3 expression was also found in the basolateral membrane of $\alpha$-tubulin-expressing cells. However, some $\alpha$-tubulin-positive cells lacked T1R3-expression, and some T1R3-positive cells lacked $\alpha$-tubulin expression, supporting the idea that T1R3 is expressed in different cell types (Figure 6, line A). No specific labeling was seen when glucose transporters and T1R3 antibodies were preincubated with the corresponding antigen peptide, or the second primary antiserum was replaced with normal serum (Figure 6, line B). In obese rats, different patterns of double labelling were found. In some animals, $\alpha$-tubulin-positive cells showed spots of T1R3 staining on the cilia and at the base of cilia, but this labelling pattern was less frequent than in lean rats (Figure 6, line $\mathrm{C}$ ). In other obese animals, the majority of $\alpha$-tubulinpositive cells lacked T1R3 coexpression. Cytoplasmic vesicles labeled for T1R3 were frequently observed in ciliated cells when cilia lacked T1R3 expression (Figure 6, line D).

\section{Ghrelin and GRLN-R expression in epithelial cells of the trachea}

Ghrelin and GRLN-R expression were investigated in the tracheal epithelium of both Wistar and Zucker rats for a better comparison of the results. The investigation was conducted using an anti-ghrelin antibody which recognizes the active, acylated form of ghrelin, a 28 amino acid sequence with an octanoyl group attached to Ser ${ }^{3}$. Ghrelin acylation is essential for the binding of the hormone to its receptor GRLN-R and to elicit its action. The immunohistochemical analysis was performed using immunoperoxidase and single or double-labeling immunofluorescence. Immunostaining was completely abolished in parallel sections by pretreatment of the antibody with the corresponding antigen peptide. In normal Wistar rats, two different cellular patterns of ghrelin expression were detected. Some cells exhibited ghrelin immunoreactivity on the apical portion that appeared with the characteristic brush of microvilli. These cells were identified as SCCs and in particular as brush cells (Figure 7A). The immunoreactive cells were solitary or in clusters of two cells. Other cells showed ghrelin immunoreactivity in cytoplasmic vesicles, localized mainly in the Golgi zone. Their apical surface was devoid of microvilli, and they were identified as secretory cells (Figure 7B and 7C). Ghrelin expression
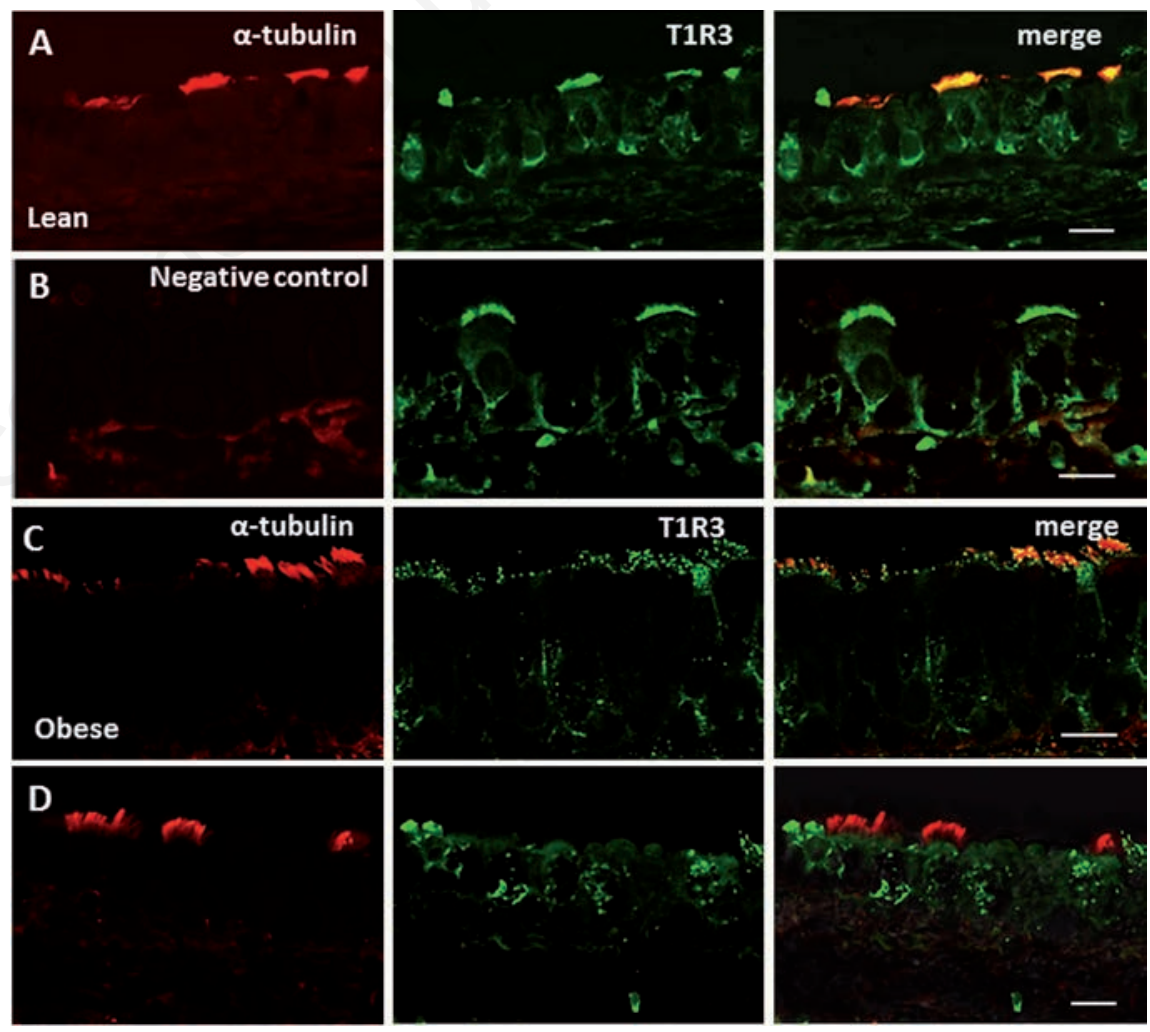

Figure 6. Double-confocal microscopy for $\alpha$-tubulin with T1R3 in trachea of Zucker rats. The immunofluorescence staining shows expression of $\alpha$-tubulin (red) with T1R3 (green) in the epithelium of lean (lines A, B) and obese (lines C, D) Zucker rats. In lean rats, $\alpha$-tubulin and T1R3 are colocalized in some spots on the cilia of tracheal cells (line A). T1R3 labeling is also observed in the apical cytoplasm beneath the cilia, and on the basolateral membrane of ciliated cells. Double-labeling is not observed when anti- $\alpha$-tubulin antibody was omitted (line B). A reduced colabelling pattern of $\alpha$-tubulin and T1R3 is observed in obese compared with lean rats, (line C). $\alpha$-tubulin-positive cells lacking T1R3 expression, and only T1R3positive cells are also observed (line D). Scale bars: $10 \mu \mathrm{m}$. 
all ciliated cells (Figure 7Q). Ghrelin expression in cytoplasmic vesicles of secretory cells was markedly reduced or absent (Figure 7R). GRLN$\mathrm{R}$ immunostaining was found in the apical portion of cells that were identified as brush cells both in Wistar and Zucker rats (Figure $8 \mathrm{~A}$ and $\mathrm{C}$, respectively). Positivity was also observed in the apical microvilli of some ciliated cells both in Wistar and Zucker rats (Figure 8B).

\section{Discussion}

Ultrastructure of the tracheal mucosa in lean and obese Zucker rats

The present study is the first, to our knowledge, to provide information on the fine structure of tracheal mucosa in lean $f a /+$ and obese falfa Zucker rats. In the majority of lean Zucker rats ( 9 animals), the tracheal mucosa presented non-obvious signs of structural alterations, especially concerning the differentiation of the various cell types that comprise the epithelium. In the remaining 3 lean animals, the tracheal mucosa alternated morphologically normal tracts, with others having an increased thickness of the lamina propria. In obese animals, the most distinctive feature of the epithelium

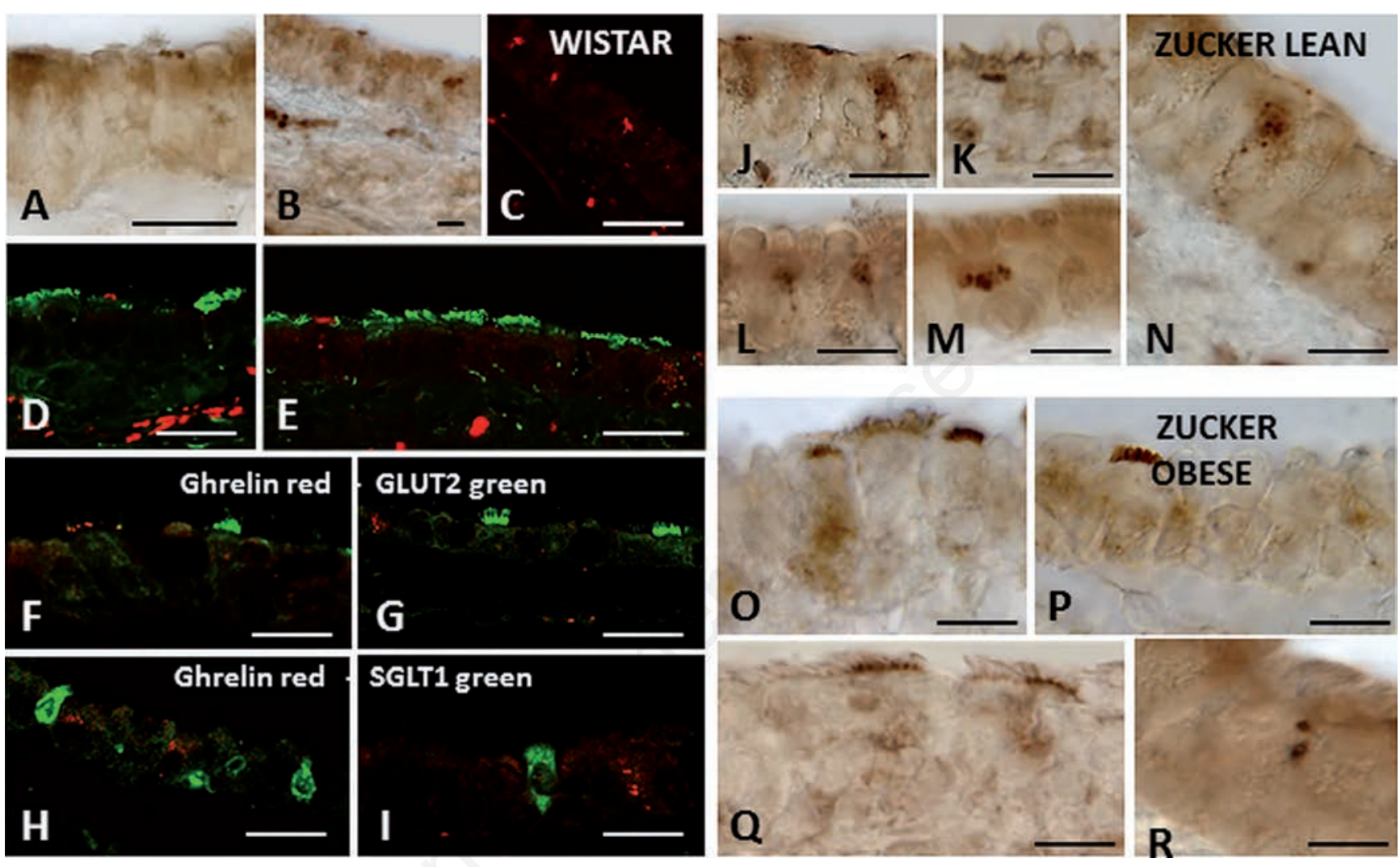

Figure 7. Ghrelin expression in trachea of Wistar and Zucker rats. Immunoperoxidase (A, B, J-R) and immunofluorescent (C-I) staining shows ghrelin immunoreactivity in the epithelium of Wistar (A-I), lean (J-N), and obese (O-R) Zucker rats. Double-immunofluorescent confocal microscopy shows ghrelin immunoreactivity (red) in cells negative for $\alpha$-tubulin (green; D, E), or GLUT2 (green; F, G), or SGLT1 (green; H, I). Scale bars: A-I) $20 \mu \mathrm{m} ; \mathrm{J}-\mathrm{R}) 15 \mu \mathrm{m}$.
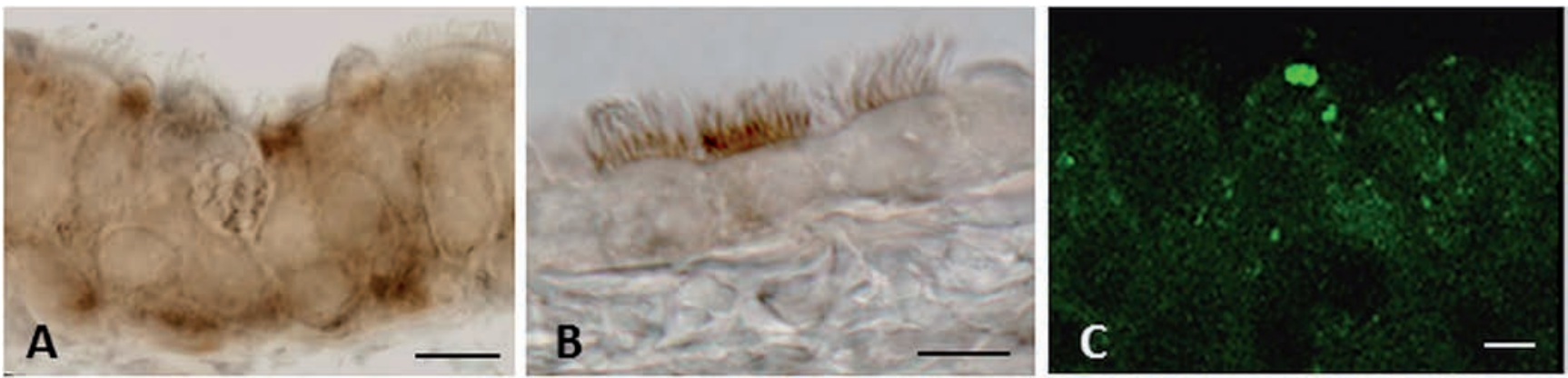

Figure 8. Ghrelin receptor (GRLN-R) expression in trachea of Wistar and Zucker rats. Immunoperoxidase (A, B) and immunofluorescent (C) staining shows GRLN-R immunoreactivity in the epithelium of Wistar (A), lean (B), and obese (C) Zucker rats. Scale bars: $9 \mu \mathrm{m}$. 
was the presence of numerous cells having morphological characteristics of intermediate cells. Two distinct types of intermediate cells were observed. One is characterized by cells with few cilia and many microvilli on the apical membrane surface; these were considered intermediate ciliated cells. The other is represented by cells with few granules, scarce cytoplasm and an abundant profile of rough endoplasmic reticulum: they were evaluated as intermediate secretory cells. In epithelia with mild morphological alterations, differentiated and intermediate cells coexisted and maintained the normal epithelial structure. In more severe alterations, the epithelium was largely composed of intermediate cells, or presented aspects of cellular depletion over large areas. Intermediate cells have already been described in the airways, and they were considered to be immature cells, probably pre-ciliated cells. ${ }^{39,40}$ Such an interpretation may be valid for our data too. The intermediate cells may represent attempts to repair epithelial damage by secretory and basal cells, which are regarded as progenitor cell pools, while ciliated cells are considered to be terminally differentiated cells, not capable of selfrenewal or trans-differentiation. ${ }^{41,42}$ However, despite the presence of an intact basal cell layer, the ciliated and secretory cells did not appear to regenerate the lost cells, either because the cells degenerated at a much fast rate than their replacement, or because the intermediate cells were not able to reach full differentiation. Unlike the other cells, the SCCs appeared well differentiated, devoid of signs of suffering and even with aspects of hypertrophy, both in lean and obese Zucker rats. The resistance of SCCs is in agreement with findings in previous studies. In particular SCCs have been described in rodents as a stable population that does not show the turnover of the surrounding epithelial cells. $^{43}$ They are terminally differentiated cells, like ciliated cells, and the majority of them are generated perinatally, but can be regenerated from proliferative basal cells after tracheal injury. ${ }^{43}$ Here, we observed clusters of SCCs in the tracheal epithelium of both Zucker rat genotypes. They were formed by cells with different morphology, thus resembling the buds of the gustatory papillae. ${ }^{44}$ We hypothesize that they represent functional units, in which cells that function as chemoreceptors coexist with cells operating as effectors; together they cooperate to respond to environmental stimuli. In this study, the ultrastructural observations of the mucosal and submucosal layers together with the quantitative evaluations have shown that morphological abnormalities (such as thickening of the basal membrane and the deposit of LDs) in the lamina propria tend to be more predominant in obese animals compared to lean rats. Moreover, the LDs deposits in the vessels and the LDs diameter in the cartilage are signif- icantly different in the two Zucker rat genotypes. In obese animals, the amorphous material observed lying beneath the epithelium constituted a layer of remarkable thickness, interposed between the basement membrane and the lamina propria. In the areas in which this matrix was of substantial thickness, the overlying epithelium was particularly badly damaged. The matrix was devoid of the typical cell population of lamina propria (i.e., fibroblasts, lymphocytes, plasma cells, macrophages, leukocytes, eosinophils). An abnormal matrix may preclude all those processes generated by interactions between adjacent cells, and bi-directional communication between the epithelium and underlying layers. ${ }^{45}$ As regards the presence of LDs, there seems to be general agreement that lipid deposits are a determining factor linking obesity with inflammatory diseases, such as asthma, since the adipokines released by lipids are regarded as responsible for the development and escalation of the inflammatory response. ${ }^{46}$ In this respect, in the lamina propria of obese rats we observed a substantial number of inflammatory cells such as eosinophils, lymphocytes, and mast cells, which are the characteristic infiltrating cells in inflammatory processes. However, no specific marker of airway inflammation was evaluated in this study because this aspect lays outside the scope of our work. On the other hand, the liposomal material in microvessels observed in this study was an unexpected result, which has not previously been described in other pathologies. We found that the difference in the area covered by lipid deposits and the respective area of the vessels was statistically significant in the two Zucker rat genotypes. Due to its characteristics of electron-density, it is reasonable to assume that the deposit was formed by lipoproteins. Similarly, we observed that the LDs diameter in the cartilage was significantly different in lean and obese rats. Their presence was detected in a previous morphological study in different mammalian species, and described as a pattern influenced by various factors including the age of the subject, and the site of the cartilage. ${ }^{45}$ The biological significance of lipid storage in healthy chondrocytes is unknown, but it is thought to be a deposit of material that can be used as a source of energy for the metabolic activity of the cell, or for other metabolic requirements of the animal. ${ }^{47}$

Taken together, our data demonstrate that substantial structural changes are a characteristic pattern of the tracheal mucosa of rats with genetic obesity.

\section{Sweet taste signaling molecules are differently expressed in tracheal epithelial cells of Zucker rats}

Our study is the first that investigates the expression of chemosensory markers and glu- cose transporters in the tracheal epithelium of lean and obese Zucker rats, and provides evidence of their differentiated expression in the two Zucker rat genotypes. In obese rats, GLUT2 expression was reduced in ciliated cells but was always located just beneath the cilia in the apical pole of the cells. Immunolabeling for SGLT1 was similar to that observed in Wistar rats. ${ }^{12}$ However, our major finding is certainly the substantial change in T1R3 expression in the tracheal epithelium of obese rats, in which T1R3 expression was strongly modified in ciliated cells. Inside these cells, T1R3 expression was reduced on the cilia, at the base of cilia in the apical cell pole, and on the basolateral membrane in some animals. In others, T1R3 immunoreactivity was not detected at these sites but appeared in cytoplasmic vesicles, irregularly distributed through the cytoplasm. This is a somewhat unrelated finding because such positivity was never observed in our previous work. ${ }^{12}$ The impaired expression of T1R3 in obese rats may be of physiological importance because it could have consequences on the chemoreceptive mechanisms linked to the specific roles of ciliated cells. Recently, important advances have been made in clarifying the role of ciliated cells. It is currently believed that they are likely to function as chemosensory cells since components (such as bitter receptors, $\alpha$-gustducin, and TRPM5) of sweet and bitter taste transduction pathways were found to be expressed on the cilia, with the function of activating pathways which increase intracellular $\mathrm{Ca}^{2+} .{ }^{15}$ These data provide strong support for the hypothesis that ciliated cells might participate in the functional detection of substances in the lumen, probably a protective response. Protection from pathogens and noxious compounds is provided by ciliary beat frequency (CBF) and mucociliary transport that are regulated by $\mathrm{Ca}^{2+}$, but the exact mechanism of this process remains controversial. ${ }^{48}$ A signal known to increase CBF is ATP-mediated activation of $G$ proteincoupled receptors which promotes the release of $\mathrm{Ca}^{2+}$. Increases in cytosolic $\mathrm{Ca}^{2+}$ are associated with increases in $\mathrm{CBF}$, but $\mathrm{Ca}^{2+}$ signals are most efficient in CBF regulation when produced at the base of the cilia. This is the site where the expression of PLC $\beta 2$ and $\alpha$-gustducin were detected by Shah's team, ${ }^{15}$ and the coexpression of T1R3 and GLUT2 by us. ${ }^{12}$ The potential involvement of T1R3 in processes involving $\mathrm{Ca}^{2+}$ signaling is unlikely to occur in obese animals given the alterations observed in both T1R3 and GLUT2 expression, with obvious effects on mucociliary clearance. However, it is interesting to note that GLUT2, SGLT1 and T1R3 expressions in SCCs are similar in obese and lean animals, suggesting that, in addition to their morphological characteristics, SCCs also preserve their immunohistochemical phe- 
notype. SCCs are a distinct cell lineage, therefore it is possible that chemoreceptor markers, although similar to those found in other cell types, are differently modulated in them.

\section{Ghrelin and GRLN-R are localized in epithelial cells of the trachea}

There is now growing evidence that ghrelin has widespread expression in many tissues, but data regarding ghrelin expression in tracheal epithelium are scarce. A single study in fetal human trachea revealed ghrelin immunoreactivity in basal cells. ${ }^{49}$ In the same study, significant expression of ghrelin was also observed in neuroendocrine and other cell types of the fetal and infant human lung, suggesting that the developing lung may be a source of circulating ghrelin in addition, of course, to the gastric mucosa.

In the present study, using immunohistochemical approaches, we provide the first evidence that ghrelin and GRLN-R are expressed in rat tracheal epithelium. Ghrelin was detected in two different cell types in both Wistar and Zucker rats, and was differentially expressed in the two Zucker rat genotypes. In obese Zucker rats, SCCs express immunoreactivity in the apical microvilli but cells with ghrelin expression in cytoplasmic vesicles were not detected. Furthermore, in some obese animals, ghrelin was also expressed in the microvilli on the apical surface of ciliated cells. We further established the presence of GRLN-R in the apical microvilli of SCCs both in Wistar and Zucker rats. These findings were consistent with the ultrastructural data, which demonstrate that SCCs are well conserved in the tracheal epithelium of obese rats, suggesting that obesity does not modulate chemosensory expression in Zucker rats, since obese $\mathrm{fa} / \mathrm{fa}$ and lean $\mathrm{fa} /+$ rats presented similar ghrelin localization in brush cells. The distinct cellular location of ghrelin suggests that it can play different roles in cellular processes: the localization on microvilli of SCCs represents a chemosensory pattern, while that in cytoplasmic vesicles is a secretory pattern. Ghrelin may function as a signaling molecule which, after binding to its specific receptor, initiates the appropriate signal transduction through $\mathrm{Ca}^{2+}$-dependent signaling pathways, GRLN-R being a G-protein-coupled receptor. ${ }^{29}$

Concerning the presence of ghrelinimmunoreactive vesicles, it is plausible to assume that they are located in the cytoplasm of secretory cells that synthesize and activate ghrelin. This is in agreement with previous observations of mouse gastric cells. ${ }^{50}$ The reduced expression of ghrelin-positive vesicles in obese Zucker rats compared with lean rats could be related to the altered secretory pattern observed at ultrastructural level. Altogether, our results indicate that two dis- tinct populations of ghrelin-expressing cells may be operative in rat trachea: SCCs might act as sensors able to detect luminal stimuli, and secretory cells as effectors that release ghrelin. In this context, it is plausible to postulate that a communication route between the two cell types may modulate the release of ghrelin according to the stimuli provided by the luminal contents. This hypothesis is consistent with similar results in the gastrointestinal tract. In the murine stomach, the expression of ghrelin has been shown in T1R3immunoreactive brush cells arranged in close contact with close-type endocrine cells expressing both T1R3 and ghrelin. In the same study, it was proposed that a chemosensory input, perceived through T1R3, induces ghrelin secretion by the endocrine cells. ${ }^{51}$ Interestingly, a subsequent report demonstrated that in the mouse stomach, ghrelin is expressed in cells located in close proximity to $\alpha$-gustducin-positive brush cells, and in endocrine cells. ${ }^{52}$ Here, it was supposed that brush cells activate the release of ghrelin by the secretory cells; whereas, the endocrine cells, which coexpress ghrelin and gustatory Gproteins, $\alpha$-gustducin and $\alpha$-transducin, act simultaneously as sensor and effector cells. The same study also provided functional evidence that activation of T2Rs bitter taste receptor stimulates ghrelin secretion and /or acylation via the $\alpha$-gustducin signaling pathway. Moreover, a recent report showed that high levels of TRPM5 mRNA correlated with a higher number and density of chemosensory cells in the gastric mucosa of obese patients. TRPM5 and ghrelin are not colocalized but expressed by neighboring cells, suggesting paracrine cell-cell communication between chemosensory cells and ghrelin-expressing cells. ${ }^{53}$ Collectively, the reported data provide clues that a link between the chemosensory system and ghrelin secretion and/or acylation exists in the gastrointestinal tract, although the exact mechanism underlying the nutrientdependent regulation of ghrelin release is not yet clear.

In accordance with these data, a similar autocrine/paracrine regulation can be proposed in the trachea. We suggest that ghrelin may be locally produced by the epithelial tracheal cells, and exert a local action through binding to GRLN-R located in proximal SCCs. Alternatively, by analogy with what happens in the intestine, it is also possible that secretion of ghrelin is induced by activation of T1Rs on the apical surface of SCCs. In this case, the reduced expression of T1R3 in obese animals may be linked to defective signaling of secretion. In line with this hypothesis, in human gastric mucosa of obese patients, decreased T1R3 mRNA was demonstrated concomitant with an increased number and density of ghre- lin-positive cells which, considering the low plasma ghrelin levels found in obesity, was interpreted as hypoactivity of ghrelin secreting cells. $^{53}$ Considering that ghrelin contributes primarily with its anti-inflammatory property to attenuate the damage produced by inflammatory mediators, such as neutrophils, chemokines, and lipopolysaccharide in various lung diseases, ${ }^{54}$ the most attractive of its role in ASL might be a protective, anti-inflammatory action against cytokines and inflammatory products released by bacteria that colonize respiratory fluids. This hypothesis was previously posited for tracheal SCCs because they were shown to be able to respond to quorum sensing molecules. ${ }^{55,56}$

Taken together, all the morphological abnormalities characterizing the tracheal mucosa of obese rats may impair their ability to maintain normal tracheal homeostasis. In obese animals, the expression of the investigated molecules (GLUT2, SGLT1, T1R3) is changed only when they are expressed in ciliated cells, and is not affected in SCCs. SCCs and ciliated cells belong to different cell lineages, and therefore may have a different susceptibility to metabolic factors and/or nutritional changes. The location and appearance of ghrelin-expressing cells strongly suggests that ghrelin can act in concert with different cell types, which reflects the level of complexity of the digestive system. Although the role of ghrelin in the airways should be further investigated, its presence can be useful for a better understanding of the pathways regulating glucose sensing and the design of new therapeutic targets for restoring glucose homeostasis in airways.

\section{References}

1. Mace 0J, Affleck J, Patel N, Kellett GL. Sweet taste receptors in rat small intestine stimulate glucose absorption through apical GLUT2. J Physiol 2007;582:379-92.

2. Margolskee RF, Dyer J, Kokrashvili Z, Salmon KS, Ilegems E, Daly K, et al. T1R3 and gustducin in gut sense sugars to regulate expression of $\mathrm{Na}+$-glucose cotransporter 1. Proc Natl Acad Sci 2007;104: 15075-80.

3. Lindemann B. Receptors and transduction in taste. Nature 2001;413:219-25.

4. Margolskee RF. Molecular mechanisms of bitter and sweet taste transduction. J Biol Chem 2002;277:1-4.

5. Sbarbati A, Osculati F. The taste cell-related diffuse chemosensory system. Prog Neurobiol 2005;75:295-07.

6. Sbarbati A, Bramanti P, Benati D, Merigo F. The diffuse chemosensory system: Exploring the iceberg toward the defini- 
tion of functional roles. Prog Neurobiol 2010;91:77-89.

7. Sbarbati A, Merigo F, Benati D, Tizzano M, Bernardi P, Osculati F. Laryngeal chemosensory clusters. Chem Senses 2004;29:683-92.

8. Finger TE, Böttger B, Hansen A, Anderson KT, Alimohammadi H, Silver WL. Solitary chemoreceptor cells in the nasal cavity serve as sentinels of respiration. Proc Natl Acad Sci 2003;100:8981-86.

9. Tizzano M, Gulbransen BD, Vandenbeuch A, Clapp TR, Herman JP, Sibhatu HM, et al. Nasal chemosensory cells use bitter taste signaling to detect irritants and bacterial signals. Proc Natl Acad Sci 2010;107:3210-15.

10. Merigo F, Benati D, Tizzano M, Osculati F, Sbarbati A. $\alpha$-Gustducin immunoreactivity in the airways. Cell Tissue Res 2005;319: 211-19.

11. Merigo F, Benati D, Di Chio M, Osculati F, Sbarbati A. Secretory cells of the airway express molecules of the chemoreceptive cascade. Cell Tissue Res 2007;327:231-47.

12. Merigo F, Benati $\mathrm{D}$, Cristofoletti $\mathrm{M}$, Amarù F, Osculati F, Sbarbati A. Glucose transporter/T1R3-expressing cells in rat tracheal epithelium. J Anat 2012;221:138-50.

13. Tizzano M, Merigo F, Sbarbati A. Evidence of solitary chemosensory cells in a large mammal: the diffuse chemosensory system in Bos Taurus airway. J Anat 2006;209: 333-37.

14. Krasteva G, Canning BJ, Hartmann P, Veres TZ, Papadakis T, Mühlfeld C, et al. Cholinergic chemosensory cells in the trachea regulate breathing. Proc Natl Acad Sci 2011;108:9478-83.

15. Shah AS, Ben-Shahar Y, Moninger TO, Kline JN, Welsh MJ. Motile cilia of human airway epithelia are chemosensory. Science 2009;325:1131-34.

16. Kalsi KK, Baker EH, Fraser 0, Chung YL, Mace 0J, Tarelli E, et al. Glucose homeostasis across human airway epithelial cell monolayers: role of diffusion, transport and metabolism. Pflugers Arch 2009;457: 1061-70.

17. de Prost N, Saumon G. Glucose transport in the lung and its role in liquid movement. Respir Physiol Neurobiol 2007;159:331-37.

18. Kalsi KK, Baker EH, Medina RA, Rice S, Wood DM, Ratoff JC, et al. Apical and basolateral localisation of GLUT2 transporters in human lung epithelial cells. Pflugers Arch 2008;456:991-3.

19. Baker EH, Wood DM, Brennan AL, Clark N, Baines DL, Philips BJ. Hyperglycaemia and pulmonary infection. Proc Nutr Soc 2006;65:227-35.

20. Pezzulo AA, Gutierrez J, Duschner KS, McConnell KS, Taft PJ, Ernst SE, et al.
Glucose depletion in the airway surface liquid is essential for sterility of the airways. PLoSOne 2011;6:e16166.

21. Philips BJ, Meguer JX, Redman J, Baker EH. Factors determining the appearance of glucose in upper and lower respiratory tract secretions. Intensive Care Med 2003;29:2204-10.

22. Wood DM, Brennan AL, Philips BJ, Baker EH. Effect of hyperglycaemia on glucose concentration of airway secretions. Cli Sci 2004;106:527-33.

23. Baker EH, Clark N, Brennan AL, Gyi KM, Hodson ME, Philips BJ, et al. Hyperglycemia and cystic fibrosis alter respiratory fluid glucose concentrations estimated by breath condensate analysis. J Appl Physiol 2007;102:1969-75.

24. Garnett JP, Nguyen TT, Moffatt JD, Pelham ER, Kalsi KK, Baker EH, et al. Proinflammatory mediators disrupt glucose homeostasis in airway surface liquid. J Immunol 2012;189:373-80.

25. Garnett JP, Gray MA, Tarran R, Brodlie M, Ward C, Baker EH, et al. Elevated paracellular glucose flux across cystic fibrosis airway epithelial monolayers is an important factor for Pseudomonas aeruginosa growth. PLoSOne 2013;8:e76283.

26. Loukides S, Polyzogopoulos D. The effect of diabetes mellitus on the outcome of patients with chronic obstructive pulmonary disease exacerbated due to respiratory infections. Respiration 1996;63:170-3.

27. Young RL. Sensing via intestinal sweet taste pathways. Front Neurosci 2011;5:23.

28. Verhulst PJ, Depoortere I. Ghrelin's second life: from appetite stimulator to glucose regulator. World J Gastroenterol 2012;18:3183-95.

29. Davenport AP, Bonner TI, Foord SM, Harmar AJ, Neubig RR, Pin JP, et al. International Union of Pharmacology. LVI. Ghrelin receptor nomenclature, distribution, and function. Pharmacol Rev 2005;57:541-6.

30. Park HK, Ahima RS. Physiology of leptin: energy homeostasis, neuroendocrine function and metabolism. Metabolism 2015;64:24-34.

31. Lutz TA, Woods SC. Overview of animal models of obesity. Curr Protoc Pharmacol 2012;5:Unit 5.61.

32. Kodama T, Ashitani J, Matsumoto N, Kangawa K, Nakazato M. Ghrelin treatment suppresses neutrophil-dominant inflammation in airways of patients with chronic respiratory infection. Pulm Pharmacol Ther 2008;21:774-9.

33. Delporte C. Structure and physiological actions of ghrelin. Scientifica 2013: 518909 .

34. Vestergaard ET, Djurhuus CB, Gjedsted J,
Nielsen S, Møller N, Holst JJ, et al. Acute effects of ghrelin administration on glucose and lipid metabolism. J Clin Endocrinol Metab 2008;93:438-44.

35. Tschop M, Weyer C, Tataranni PA, Devanarayan V, Ravussin E, Heiman MI Circulating ghrelin levels are decreased in human obesity. Diabetes 2001;50:707-9.

36. Scerif M, Goldstone AP, Korbonits M. Ghrelin in obesity and endocrine diseases. Mol Cell Endocrinol 2011;340:15-25.

37. Lewis Carl SA, Gillete-Ferguson I, Ferguson DG. An indirect immunofluorescence procedure for staining the same cryosection with two mouse monoclonal primary antibodies. J Histochem Cytochem 1993;41:273-8.

38. Negoescu A, Labat-Moleur F, Lorimier P, Lamarcq L, Guillermet C, Chambaz E, Brambilla E. F(ab) secondary antibodies: a general method for double immunolabeling with primary antisera from the same species. Efficiency control by chemiluminescence. J Histochem Cytochem 1994;42: 433-7.

39. Jeffery PK, Reid L. New observations of rat airway epithelium: a quantitative and electronmicroscopic study. J Anat 1975;120: 295-20.

40. Nikula KJ, Wilson DW, Giri SN, Plopper CG, Dungworth DL. The response of the rat tracheal epithelium to ozone exposure. Injury, adaptation, and repair. Am J Pathol 1988;131:373-84.

41. Cole BB, Smith RW, Jenkins KM, Graham BB, Reynolds PR, Reynolds SD. Tracheal basal cells: a facultative progenitor cell pool. Am J Pathol 2010;177:362-76.

42. Rawlins EL, Hogan BL. Ciliated epithelial cell lifespan in the mouse trachea and lung. Am J Physiol Lung Cell Mol Physiol 2008;295:L231-4.

43. Saunders CJ, Reynolds SD, Finger TE. Chemosensory Brush Cells of the Trachea. A Stable Population in a Dynamic Epithelium. Am J Respir Cell Mol Biol 2013;49:190-6.

44. Chandrashekar J, Hoon MA, Ryba NJ, Zuker CS. The receptors and cells for mammalian taste. Nature 2006;444:288-94.

45. Knight DA, Holgate ST. The airway epithelium: structural and functional properties in health and disease. Respirology 2003;8:432-46.

46. Foster DJ, Ravikumar P, Bellotto DJ, Unger RH, Hsia CC. Fatty diabetic lung: altered alveolar structure and surfactant protein expression. Am J Physiol Lung Cell Mol Physiol 2010;298:L392-3.

47. Collins DH, Ghadially FN, Meachim G. Intra-cellular lipids of cartilage. Ann Rheum Dis 1965;24:123-35.

48. Davis CW, Lazarowski E. Coupling of air- 
way ciliary activity and mucin secretion to mechanical stresses by purinergic signaling. Respir Physiol Neurobiol 2008;163: 208-13.

49. Volante M, Fulcheri E, Allìa E, Cerrato M, Pucci A, Papotti M. Ghrelin expression in fetal, infant, and adult human lung. $\mathrm{J}$ Histochem Cytochem 2002;50:1013-21.

50. Sakata I, Yang J, Lee CE, OsborneLawrence S, Rovinsky SA, Elmquist JK, et al. Colocalization of ghrelin 0-acyltransferase and ghrelin in gastric mucosal cells. Am J Physiol Endocrinol Metab 2009;297: E134-41.

51. Hass N, Schwarzenbacher K, Breer H.
T1R3 is expressed in brush cells and ghrelin-producing cells of murine stomach. Cell Tissue Res 2010;339:493-4.

52. Janssen S, Laermans J, Verhulst PJ, Thijs T, Tack J, Depoortere I. Bitter taste receptors and $\alpha$-gus tducin regulate the secretion of ghrelin with functional effects on food intake and gastric emptying. Proc Natl Acad Sci 2011;108:2094-9.

53. Widmayer $P$, Küper $M$, Kramer $M$, Königsrainer A, Breer H. Altered expression of gustatory-signaling elements in gastric tissue of morbidly obese patients. Int J Obes 2012;36:1353-59.

54. Kodama T, Ashitani J, Matsumoto N,
Kangawa K, Nakazato M. Ghrelin treatment suppresses neutrophil-dominant inflammation in airways of patients with chronic respiratory infection. Pulm Pharmacol Ther 2008;21:774-9.

55. Sbarbati A, Tizzano M, Merigo F, Benati D, Nicolato E, Boschi F, et al. Acyl homoserine lactones induce early response in the airway. Anat Rec 2009;292:439-48.

56. Krasteva G, Canning BJ, Papadakis T, Kummer W. Cholinergic brush cells in the trachea mediate respiratory responses to quorum sensing molecules. Life Sci 2012; 91:992-6. 